\title{
United Kingdom Policies for a Sustainable Recovery
}
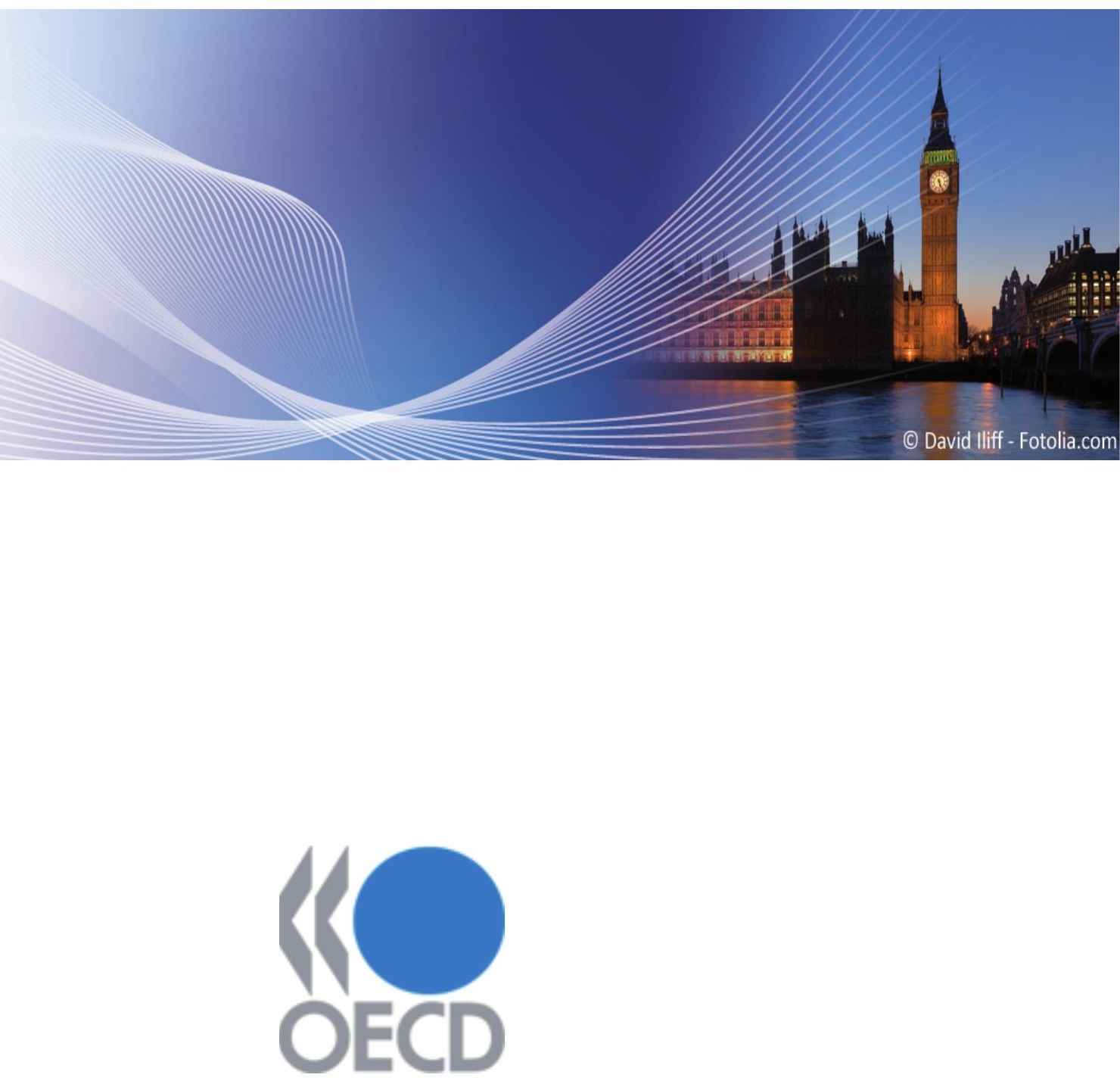
Better Policies

\section{United Kingdom: Policies for a Sustainable Recovery}




This work is published on the responsibility of the Secretary-General of the OECD. The opinions expressed and arguments employed herein do not necessarily reflect the official views of the Organisation or of the governments of its member countries.

This document and any map included herein are without prejudice to the status of or sovereignty over any territory, to the delimitation of international frontiers and boundaries and to the name of any territory, city or area.

ISBN 978-92-64-20177-4 (PDF)

Series: Better Policies

ISSN 2308-1392 (online)

The statistical data for Israel are supplied by and under the responsibility of the relevant Israeli authorities. The use of such data by the OECD is without prejudice to the status of the Golan Heights, East Jerusalem and Israeli settlements in the West Bank under the terms of international law.

Photo credits: Cover $\odot$ David lliff - Fotolia.com

Corrigenda to OECD publications may be found on line at: www.oecd.org/publishing/corrigenda.

(c) OECD 2013

You can copy, download or print OECD content for your own use, and you can include excerpts from OECD publications, databases and multimedia products in your own documents, presentations, blogs, websites and teaching materials, provided that suitable acknowledgment of the source and copyright owner is given. All requests for public or commercial use and translation rights should be submitted to rights@oecd.org. Requests for permission to photocopy portions of this material for public or commercial use shall be addressed directly to the Copyright Clearance Center (CCC) at info@copyright.com or the Centre français d'exploitation du droit de copie (CFC) at contact@cfcopies.com. 


\section{Contents}

Preface

A Strategy to Instil Confidence and Boost Growth

Financial Markets

Innovation and ICT

Green Growth and Climate Change

Education

Employment

Equity

Health

Tax Policies

Public Governance

Regional Policy 


\section{Preface}

The world is emerging from the most severe economic crisis of our lifetimes. Yet, the social and human costs are high, and the ability of our economies to grow and prosper will depend more than ever on the quality of government actions and on strong and effective international co-operation. Restoring stability, confidence and growth remains the priority.

The OECD has been working with the world's governments and other organisations to overcome the crisis and get our economies moving again. It is helping to shape the post-crisis world economy - to make it stronger, cleaner and fairer.

We need to deliver higher growth, job creation, poverty reduction and lower deficits. Any effective strategy requires major re-thinking about the sources of future growth, about innovation and "greener", low carbon opportunities. We need to strike a "New Balance", between markets and governments; between recovery and fiscal consolidation.

As the UK focuses on the challenges to build a new growth model based upon its exceptional economic and social strengths, it has to become more productive and more competitive. Thus, if the UK's recovery is to become sustainable, policy action on a broad front is required.

This brochure was prepared by the OECD to suggest the main policy challenges of the UK, based on our own knowledge of its economy, as well as on the practices and reforms that have worked well in other countries. It proposes a strategy to instil confidence and boost growth, accompanied by action plans in each of the following 10 critical areas: I) Financial Markets; II) Innovation and ICT; III) Green Growth and Climate Change; IV) Education; V) Employment; VI) Equity; VII) Health; VIII) Tax Policies; IX) Public Governance; and X) Regional Policy.

The OECD is committed to continue working with the UK government in shaping policies and solutions to successfully face these challenges.

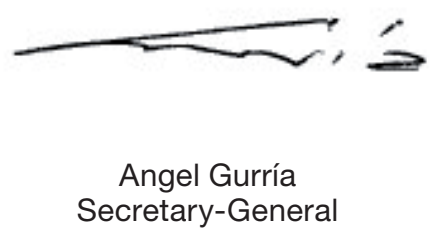




\section{A Strategy to Instil Confidence and Boost Growth}

With an economy very open to investment and trade, and highly exposed to developments in global financial markets, the UK was hard hit by the economic and financial crisis.

A modest recovery is now under way, but the effects of the crisis, on output, on employment and on government accounts, linger. Potential output may have fallen by up to 3 per cent, in large part as a result of the shrinking of the financial sector. Unemployment, currently at 8 per cent, is about 3 percentage points above the 2000-2007 average and is expected to fall only modestly in the next couple of years. Last but not least, fiscal accounts have deteriorated sharply, with large deficits and rising debt levels.

\section{Playing on the UK's strengths to improve the basis for longer-term growth}

Current policy challenges may seem daunting, but the UK has great strengths and with the right policy mix is among the countries best positioned to flourish in an increasingly knowledge-based world economy, including by assuming a leadership position in realising the promises of a green, "low-carbon", growth model.

The presence of world-class higher education institutions, a business-friendly regulatory framework which encourages entrepreneurship, well-developed venture capital markets, wide access to efficient communication networks, including high broadband penetration rates and a tolerant and modern society which helps attract a multi-cultural talent pool from around the globe are all factors that make the UK one of the most innovative and entrepreneurial societies in the world. The UK is also a leading light on policies to combat climate change and foster the development of a low-carbon economy.

These are solid foundations on which to build upon. But to translate these strengths into a sustained increase in productivity growth, the UK also needs to tackle some structural weaknesses which have held it back in the past. This is also the key to reconcile the need to move to a more sustainable fiscal position on one hand, with the fight against unemployment and the support for the nascent recovery on the other.

The main ingredient to move away from the false dilemma between stimulus and consolidation is confidence. Only with the full return of confidence will we have the right environment for private demand to take over from the government and sustain the recovery.

The UK government can bolster confidence in at least three related ways:

First, a credible fiscal consolidation plan. The comprehensive budget announced by the government on 22 June was courageous and appropriate. It was an essential starting point. It signals the commitment to provide the necessary degree of fiscal consolidation over the coming years to bring public finances to a sustainable path, while still supporting the recovery.

Second, a strategyto tacklestructural problems. UK productivity is hampered by slow or partially implemented structural reforms to public services and low levels of resource utilisation. Healthcare and education services are relatively inefficient and income inequality has increased considerably. Furthermore, even though the UK labour market is characterised by a relatively low burden of employment regulations, the current downturn has highlighted the need to reform labour institutions, so they can provide better targeted support to fragile groups. Bolder measures are also needed to ensure that unemployment does not become entrenched.

Third, the UK should increase its ability to tap new sources of growth. Innovation explains up to twothirds of labour productivity gains over the period 2000-07 in the UK. Innovation is essential to strengthen competitiveness. Although the UK is a very innovative society, much can still be done to boost the positive spillovers from its knowledge base to productivity, including through better efforts at commercialisation of innovation. The UK could also do more to realign economic and environmental objectives and to unleash the opportunities for green investment, including through the more efficient use of green tax instruments. 
The sources of real income differences, 2008

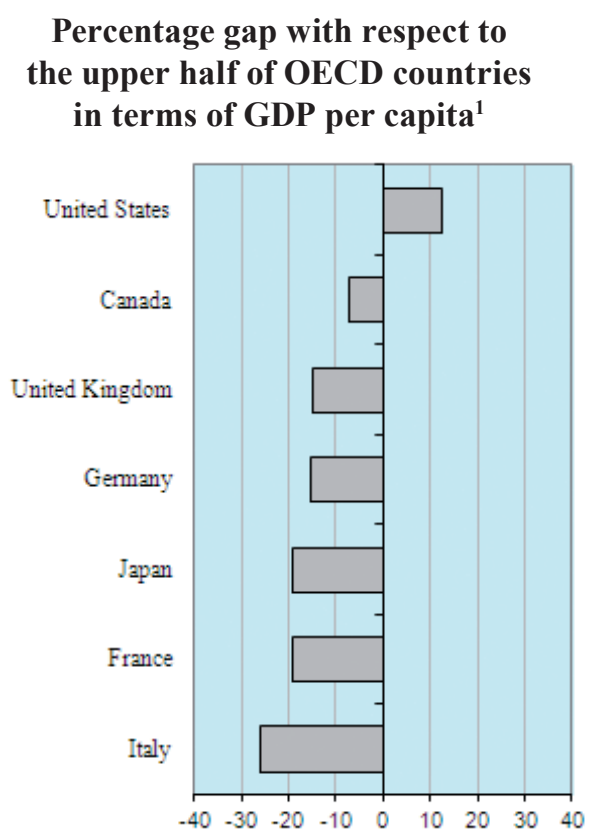

\section{Percentage gap for labour resource utilisation ${ }^{2}$}

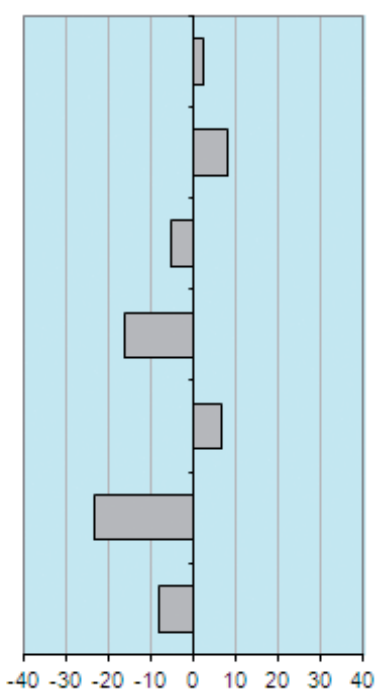

Percentage gap for labour productivity ${ }^{3}$

1. Relative to the simple average of the highest 15 OECD countries in terms of GDP per capita, based on 2008 purchasing power parities (PPPs). The sum of the percentage gap in labour resource utilisation and labour productivity do not add up exactly to the GDP per capita gap since the decomposition is multiplicative.

2. Labour resource utilisation is measured as total number of hours worked per capita.

3. Labour productivity is measured as GDP per hour worked.

Source: OECD National Accounts database; OECD Economic Outlook 86 database and OECD (2009), OECD Employment Outlook 2009. 


\section{Key OECD Recommendations}

- Ensure fiscal sustainability. Implement the consolidation plan. Raise the retirement age to improve fiscal sustainability. Ensure full independence for the recently created Office for Budget Responsibility.

- Reform the regulatory framework for the financial sector. Ensure appropriate regulation and supervision of the financial system, both through national measures and constructive engagement at the international and European level. Create a "firewall" between high risk investment banking and commercial banking.

- Improve educational outcomes. Increase participation in quality early-childhood education. Improve educational outcomes and skill formation, especially among disadvantaged children. Discourage early leaving from the education system. Increase the quality of vocational training and the availability of high-quality apprenticeship positions to ensure that relevant skills are provided.

- Increase efforts to make work pay and to help workers to find and retain work. Ensure adequate staffing of Public Employment Services and target existing activation efforts on the most disadvantaged and hardest-to-place youth.

- Tackle high levels of disability benefit claimants. Ensure that all claimants are covered by the announced Work Program scheme. Monitor health status earlier and more frequently in the workforce.

- Pursue public sector reforms to improve productivity. Improve productivity and control costs in health care by containing capitation fees and wages. Reinforce competition among health care providers to mitigate price pressures. Raise consistency in the allocation of health care responsibility across government bodies. Improve productivity in education (e.g. through further decentralisation of decision making).

- Promote green growth. Further enhance integration of environmental concerns into national and sectoral policies in order to move towards green growth and create incentives for the private sector to invest in green technologies and undertake climate adaptation actions. Turn the Climate Change Levy into a fullfledged carbon tax. Abolish the reduced VAT rate for domestic energy use and reassess the economic and environmental efficiency of other green taxes.

- Increase the efficiency of the tax system. Address the economic and environmental inefficiencies in the VAT system created by exemptions and reduced rates.

- Prioritise investment in innovation, infrastructure and R\&D. While fiscal consolidation makes severe budget cuts necessary, growth enhancing activities such as infrastructure, green investment and R\&D spending should be prioritised. Implement a national road pricing scheme to mitigate road congestion.

- Improve the functioning of the housing market. Make the planning system more flexible, more predictable and provide incentives for local communities to release land for building, while continuing to protect the environment. Shift property taxation from stamp duties towards recurrent taxes based on market property values. 


\section{Financial Markets}

The UK financial system has been severely affected by the financial crisis, which exposed weaknesses in the supervisory, crisis management and resolution frameworks. The UK financial market is highly developed, dynamic and internationally open. The strong dynamism of the sector was a major factor in supporting aggregate output growth. The speed at which it expanded over the past decade is without comparison except in Ireland. Total banking assets in the UK are over five times GDP, a much higher multiple than in the euro area. Against this background, sound regulation and supervision are all the more important in ensuring that financial market institutions, particularly banks, function well and that financial stability is sustained. Restoring a sound financial system is a prerequisite for sustained economic growth.

\section{What are the key challenges?}

Proposals for financial reform are included in the Turner Review and at an international level in the Basel III proposal and several European Commission initiatives. Constructive engagement at the international and European level will be essential to securing the best outcomes for financial reforms. In conceiving institutional reforms, the UK should consider the OECD's recent Policy Framework for Effective and Efficient Financial Regulation, which addresses, at a high level, the issue of institutional design. Policy objectives of each of the supervisory and regulatory authorities should be clearly specified, with clear accountability mechanisms, maximising synergies, consistency and coherence, avoiding potential conflicts of interest and minimising the exposure of the taxpayer to future crises. The Government has recently decided that the Bank of England should be given control over macro-prudential regulation and oversight of micro-prudential regulation. In this context, the key issue within the $\mathrm{BoE}$ will be to set up a governance structure that allows informational synergies, while separating accountability in decision making.

\section{Recommendations}

Regulations need to ensure that banks avoid excessive leverage and risk taking. Sound corporate governance, high disclosure and accountability standards and risk-management culture should be fostered. Lending standards and alignment of incentives with long-term value creation should receive greater regulatory and supervisory attention. Liquidity positions of financial institutions should also be carefully monitored. Capital requirements should be reinforced as set out in the Basel III proposal. In this respect the OECD has much more confidence in the role of a leverage ratio than in the risk weight of assets for purposes of minimum capital adequacy. This is because the weight scheme opens up too much scope for capital arbitrage. As indicated in Figure 1, in the UK crisis-related losses and leverage ratios of banks that reported such losses were among the highest in a sample of OECD countries. Trading of CDS and related products on centralised exchanges should be encouraged, adding transparency and allowing for exchanges to play a greater role in guaranteeing delivery on financial commitments. Dynamic provisioning would reduce pro-cyclicality in lending. Reporting and accounting standards should give preference to mark-to-market over amortised cost accounting for capital market products. External credit ratings should be used with due caution by regulators and supervisors in the assessment of the riskiness of banks' activities and should not substitute for their own analysis. The deposit insurance scheme has been strengthened by raising coverage, removing coinsurance and renewed attention to the operational aspects, but consideration could be given to introducing risk-based premia along the lines of schemes used in some other OECD countries. Consideration should also be given to what lessons can be learnt from the more rules-based approaches to supervision practiced in other OECD countries. 


\section{For a stronger, cleaner:

\section{Leverage vs. losses}

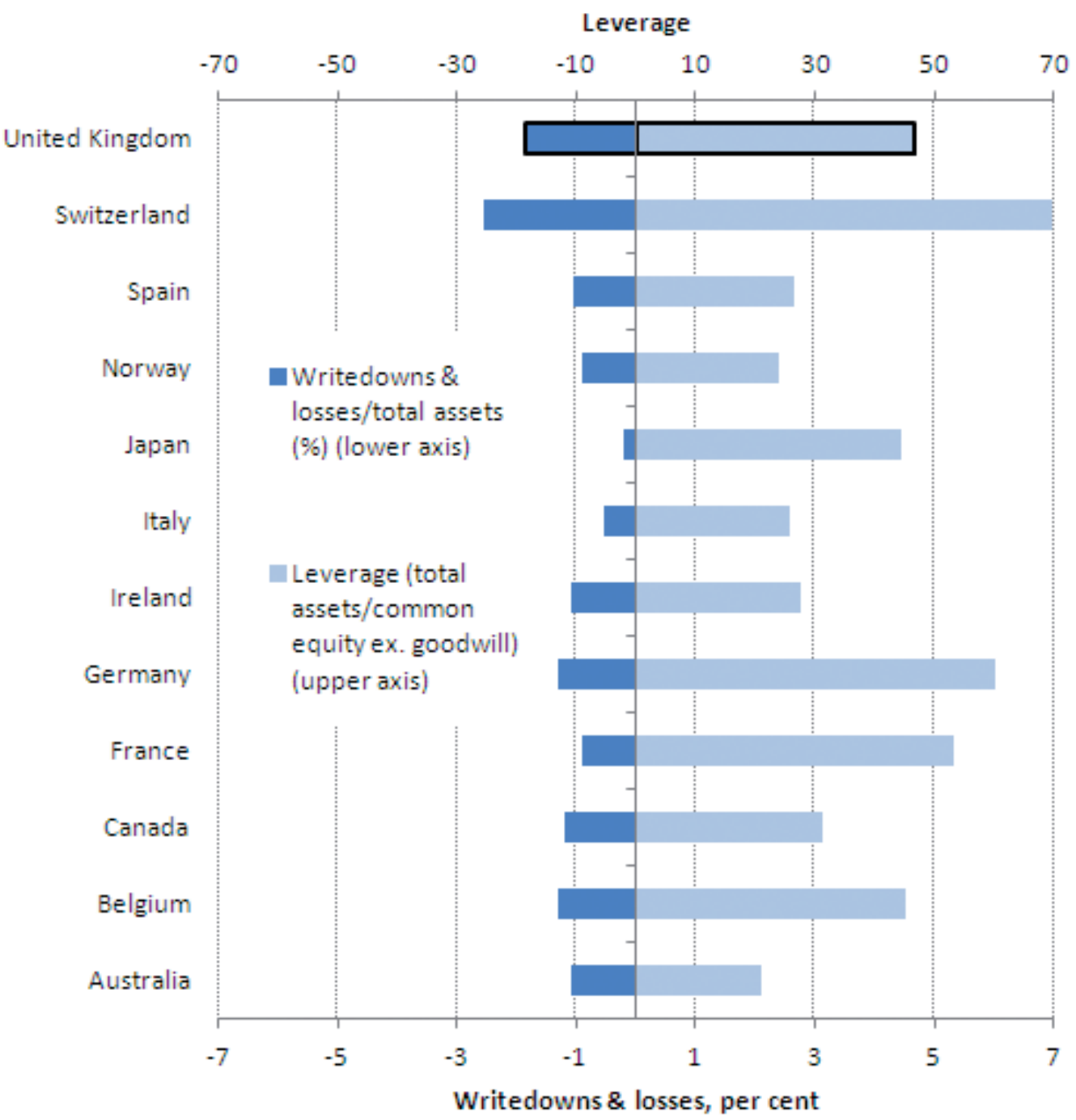

Note: Calculations based on the sample of banks reporting write-downs and credit losses as reported by Bloomberg, excluding US banks. Writedowns $\&$ losses are accumulated over 2007 - 2009; total assets and common equity are averages of 2006-2008 end-of-year data.

Source: Bloomberg, Worldscope, Thomson Reuters Datastream, and OECD.

High risk investment banking should not be mixed with commercial banking. While there are many ways to go about the separation in practice, the OECD favours a firewalled non-operating holding company structure. Firewall structures are needed to prevent the switch of capital and/or assets between subsidiaries in a crisis. The results (and recommendations drawn thereof) of the commission to examine the impact of the structure of the UK banking model on businesses and individuals, which will include looking at the universal banking model, will be crucial. As essential tools to deal with contagion and counterparty risk that are so integral to the 'too big to fail' issue, firewalled non-operating holding company structures should be complemented by group leverage ratios that could provide binding capital constraints. Capital market banks, especially when large and systemically important need to be specifically supervised, subject to capital rules where trading book requirements are appropriate to the risk they take, and they should be accompanied by resolution regimes including living wills. 
Financial reforms need to overcome access to finance constraints for business-led innovation and encourage a better balance between the search for return and prudence with regard to risk. Well-functioning venture capital markets and the securitisation of innovation-related assets are important and need to be developed further. Securitisation, which has suffered during the crisis, needs to be revived or kick-started. Establishing standards and ensuring transparency should be considered. Over time, the legal and regulatory framework should be reviewed to ensure that there are no undue barriers to the development of a covered bond market or the well-functioning of the securitisation market.

The OECD highly welcomes the new focus on consumer protection and financial education as reflected in the National Strategy for Financial Capability and a new Consumer Financial Education Body established by the Financial Services Act in April 2010. Regard should be given to the OECD Council Recommendations in this area. Any measures in this area need to strike a balance between the benefits of innovation and product suitability. Results from the 2009-10 OECD survey of financial consumer protection regulatory regimes in 35 countries could be helpful in pointing towards best practices in this regard. Measures should also be based on the notion that the success of any government policy in the areas of consumer protection is conditioned by two essential underlying elements: (i) the need for consumers to have a minimum level of financial literacy; and (ii) the importance for policymakers of understanding behavioural and attitudinal factors leading consumers to make specific decisions and choices.

\section{Key OECD Recommendations}

- Capital adequacy standards should be strengthened to ensure that banks have a sufficient capital cushion for the risks being undertaken. Banks should be required to hold adequate capital for off-balance sheet risks, so as to counter regulatory arbitrage and reputational risks. Consistent with this, the accounting treatment of off-balance sheet assets should be aligned with the underlying risks. A leverage ratio should be a primary tool.

- Liquidity positions of financial institutions should be closely monitored.

- Lending standards and alignment of incentives with long-term value creation should receive greater regulatory and supervisory attention.

- External credit ratings should be used with due caution by regulators and supervisors in the assessment of the riskiness of banks' activities and should not substitute for their own analysis.

- The pro-cyclicality of the financial system should be dampened. Consideration should be given to the use of an overall leverage ratio, covering all relevant assets, and dynamic provisioning. The development of other instruments should also be considered. In general, a rules-base framework may be more effective than discretion.

- There should be a "firewall" between higher risk investment banking and commercial banking.

- The legal and regulatory framework should be reviewed to ensure that there are no undue barriers to the development of a covered bond market or the well functioning of the securitisation market.

- Consumer protection and financial education should be promoted. 


\section{Innovation and ICT}

Innovation is a cornerstone of our economies. Over the period 2001-2007, average UK labour productivity growth was $2.1 \%$, with up to two-thirds of that being accounted for by factors associated with innovation.

\section{What are the challenges?}

The global downturn has diminished growth. If the UK is to return quickly to innovation-led growth then it needs to continue to do what it is good at and address quickly what it is not so good at. The United Kingdom performs strongly on a range of science and innovation indicators (Figure 1). The outputs from the science base are well above the OECD average as judged by the volume of scientific articles, only coming behind the United States, China and Japan in terms of total numbers worldwide. In addition, it does well in terms of the number of articles per million of population - ranking 12th worldwide and well above the average (2008 data). The UK does well too in terms of attracting finance for innovation, both from abroad and from venture capital funds, contributing $13 \%$ of total OECD venture capital in 2008, though there has been a recent downward trend.

\section{Science and innovation profile of the UK}

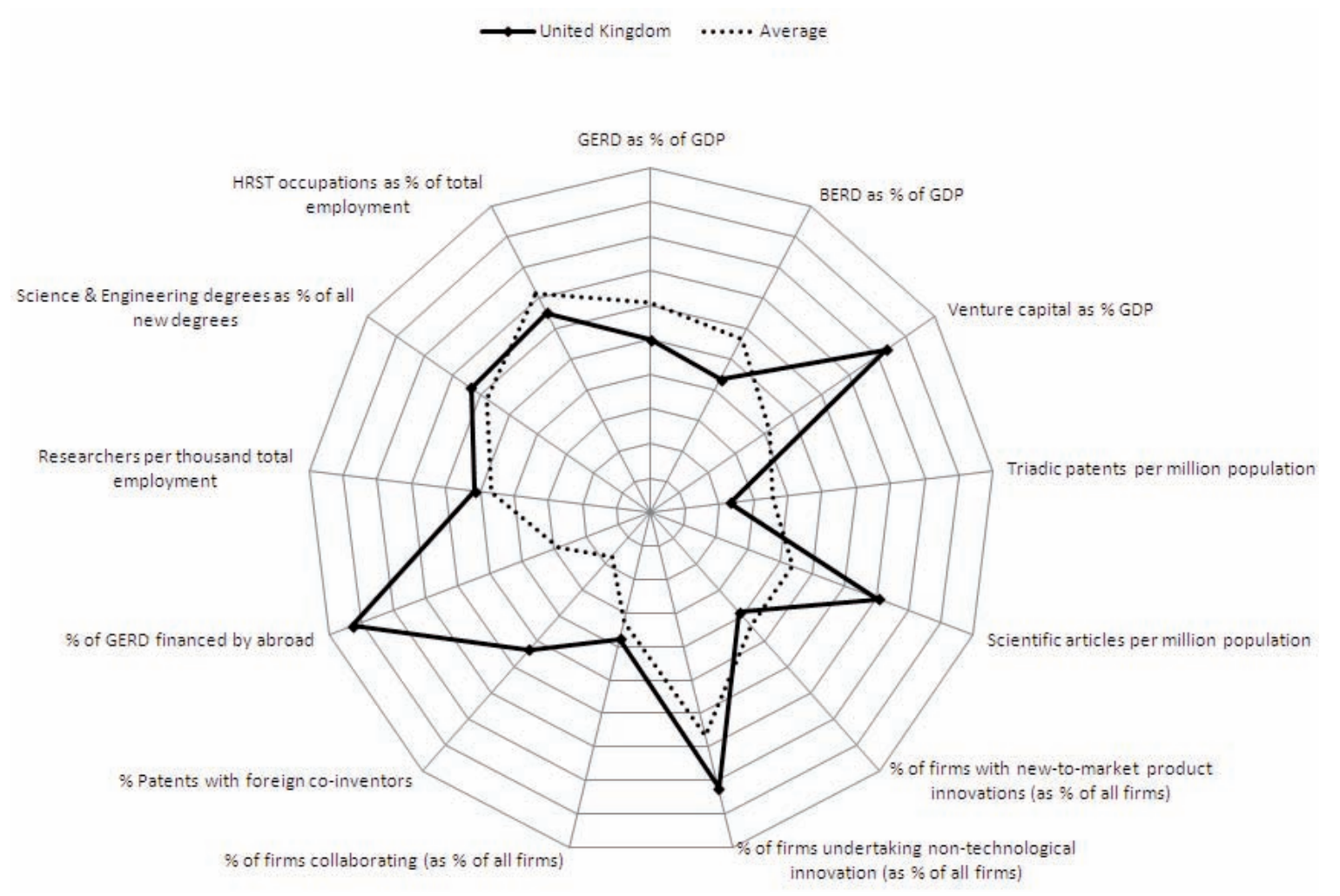

Source: OECD "STI Outlook 2010" (forthcoming)

Gross expenditure on R\&D (GERD) was below the OECD average in 2008 (1.9\% of GDP compared with the OECD average of 2.3\%), as was business expenditure on R\&D (BERD) (1.2\% of GDP compared with an OECD average of 1.6\%). This mainly reflects the UK's industrial structure with a small manufacturing base and a large financial services sector. The challenge is to foster innovation across a wide range of sectors, including in new emerging industries where the UK may be able to develop a comparative advantage. This will require preserving - to the extent possible - high-quality investment in research and human capital that can provide the seeds for new growth. 
Firms' turnover from product innovation, by type of innovator, 2006 (as a percentage of total turnover) ${ }^{1}$



${ }^{1}$ New-to-market product innovations are new or significantly improved goods or services introduced to the firm's market before its competitors, while new-to-the-firm product innovations are goods and services already available on the market.

Source: OECD, Measuring Innovation - A New Perspective, 2010.

The largest challenge is turning the UK's high-quality research into stronger innovation performance and productivity. Compared with many other European countries, links between science and industry in the United Kingdom are reasonably well developed. However, firms in the UK derive only little turnover from innovation (Figure 2). Patent performance - an indicator of turning knowledge into wealth - also lags in terms of the UK share of "triadic " patents per million of the population. In addition, the percentage of firms (12\%) that introduced new-to-market product innovations during 2004-06 was slightly below the OECD average (14\%), although an above average $44 \%$ of firms conducted non-technological innovation during the same period.

Direct and indirect government funding of business R\&D, 2007



Source: OECD, Measuring Innovation - A New Perspective, 2010.

\section{Recommendations}

R\&D tax credits can be a relatively attractive incentive mechanism to encourage innovation and are used extensively in a number of OECD countries, including the United Kingdom (Figure 3). However, in assessing the overall amount of tax relief in support of $R \& D$, it is important for policy makers to examine not only $R \& D$ 
expenditures, but also the tax treatment of returns on that investment, including the jurisdiction in which those returns are taxed. There is clear recognition, reiterated in the 22 June Budget Report, that the business environment for private sector investment in the UK remains key to balanced and sustainable growth. The commitment to "consult with business to review the taxation of intellectual property [and] the support $R \& D$ tax credits provide for innovation" is thus welcome.

As in other OECD countries, current UK policies to strengthen innovation mainly focus on the supply of knowledge and inventions through investment in basic $R \& D$ and support for private-sector $R \& D$. These policies are important, but attention also needs to be given to making markets work better for innovation and increasing the uptake of innovation by society. Such policies need not be costly; they can be very effective if well-designed and based on a sound policy rationale. Well-designed demand-side policies are not directed at specific firms, but reward innovation and efficiency. Green tax reforms, for example, can encourage environmental innovation. Better and smarter regulation can also help increase the uptake of innovation. Better use of public procurement can also be effective, in particular when government is a large consumer.

Entrepreneurship also needs to be central to any strategy to strengthen innovation. New and young firms are particularly important, as they often exploit technological or commercial opportunities that have been neglected by more established companies. A policy environment that fosters the start-up and expansion of new firms is therefore critical for innovation to flourish.

Weaknesses in education and skills continue to be a constraint on innovation and productivity in the UK. While the UK ranks reasonably high on PISA indicators of science achievement, it does less well on mathematics and reading, and the evidence shows that a relatively large share of UK students does very poorly. Raising education and training levels therefore has to remain a priority in strengthening innovation and productivity, and in enabling the low-skilled to find jobs.

OECD Fixed broadband subscribers per 100 inhabitants, by technology, December 2009

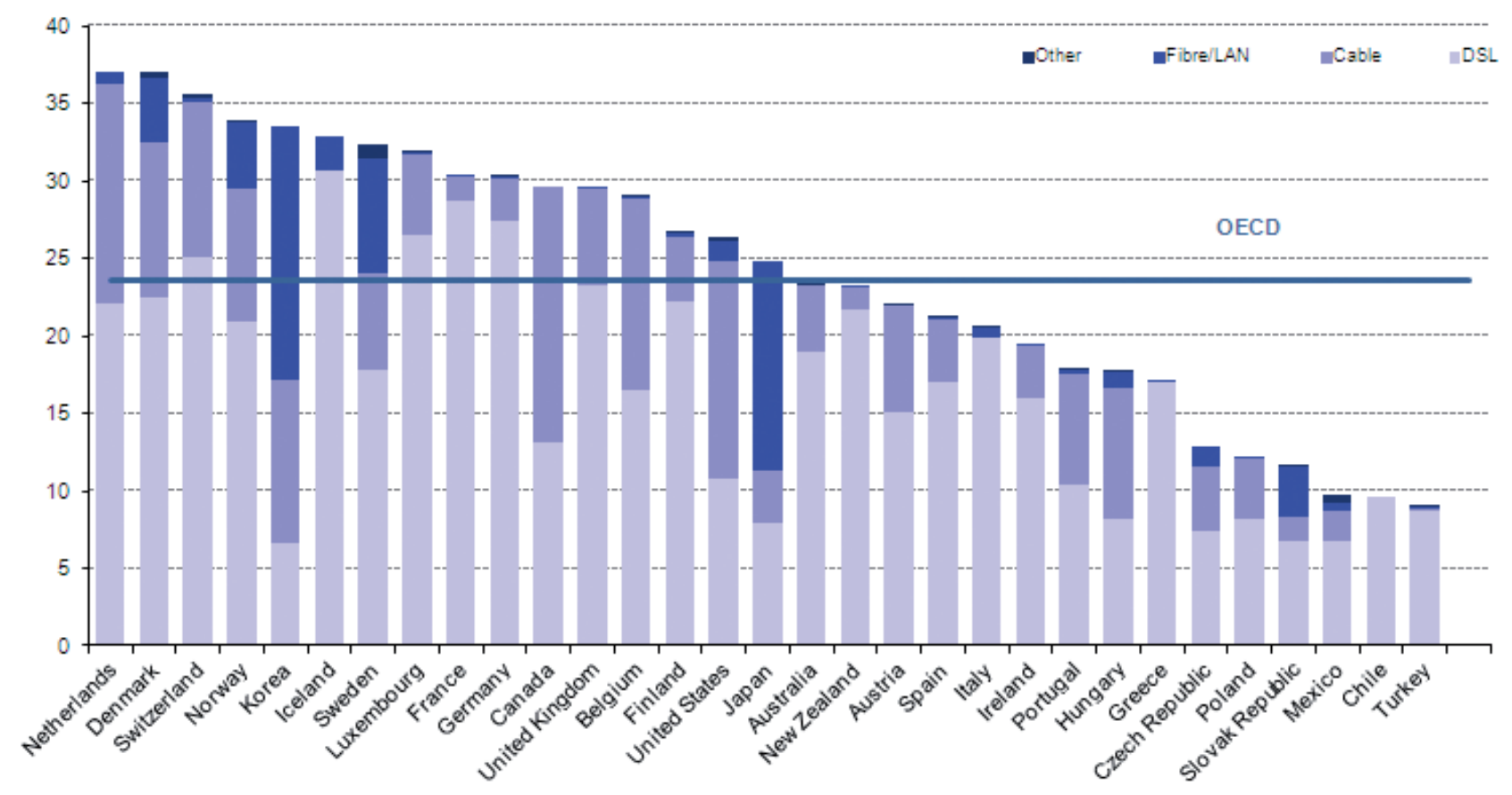


Today, high-speed communication networks support innovation throughout the economy much as electricity and transport networks spurred innovation in the past. Broadband networks provide a platform for the development and diffusion of smart infrastructures (energy, health, transport, education). Governments should promote this symbiotic relationship and ensure that broadband is available throughout their territory. Such investments must be accompanied by regulatory frameworks that support open access to networks and competition in the market. In addition to their hardware and software, ICT infrastructure carries publicly generated or funded information. Provision of this information at no or low cost can stimulate innovation and improve the transparency and efficiency of government.

The UK telecommunication market is among the most competitive in the OECD and prices are relatively low as a result. Across all the mobile telecommunication baskets of the OECD, the UK has consistently been among the top four least-expensive countries. Broadband penetration in the UK is 29 subscribers per 100 inhabitants, higher than the OECD average (Figure 4), and the UK also leads the OECD in terms of broadband affordability. While broadband prices in the UK are low, the advertised speeds lag those in many other OECD countries.

Following BT's decision to split the company into two (retail and wholesale), subscribers in the UK now enjoy even more competition. However, BT is lagging in upgrading its network, which leads to the question of whether there is sufficient incentive for BT now to upgrade its network to fibre - the next generation of broadband connectivity.

Key OECD Recommendations

- Protect high-quality investments in research, infrastructure and education, as these provide the seeds for future growth. At the same time, continue to explore ways of making government policies in support of innovation more efficient and to innovate in the delivery of public services.

- Strengthen the commercialisation of knowledge. Turning the UK's high-quality research into stronger innovation performance and productivity is a key challenge. It requires strengthening the cooperation between science and industry, and a greater focus on well-designed demand policies that can make markets work for innovation.

- Strengthen the effectiveness of tax support for R\&D. Follow through the review of the tax treatment of intellectual property and credits for R\&D to strengthen the business environment for innovation. Ensure that intellectual property rights resulting from reform are of good quality and not used anti-competitively.

- Give greater room for new firms: policy needs to give room for healthy risk-taking and creativity, including by removing barriers to firm growth and by encouraging competition from start-up firms.

- Strengthen investment in workforce skills. Innovation and productivity growth rely on broad and relevant education as well as wide-ranging skills that complement formal education. Augment the UK's relatively strong science and technology skills with entrepreneurial, business and finance skills needed to translate research into marketable innovations. Make education and training a priority.

- Continue to ensure strong competition in the telecommunications market. Policy makers in the UK need to carefully consider their broadband strategy to ensure that the proper incentives are in place to roll out next-generation access networks based on fibre across the country. 


\section{For a stronger, cleaner

\section{Green Growth and Climate Change}

The UK has taken important steps to strengthen its policies and institutional frameworks to green its economy. In order to move further towards green growth and to fully benefit from this new source of growth, the UK government will have to further realign economic and environmental objectives in national and sectoral policies.

\section{What are the main issues and challenges?}

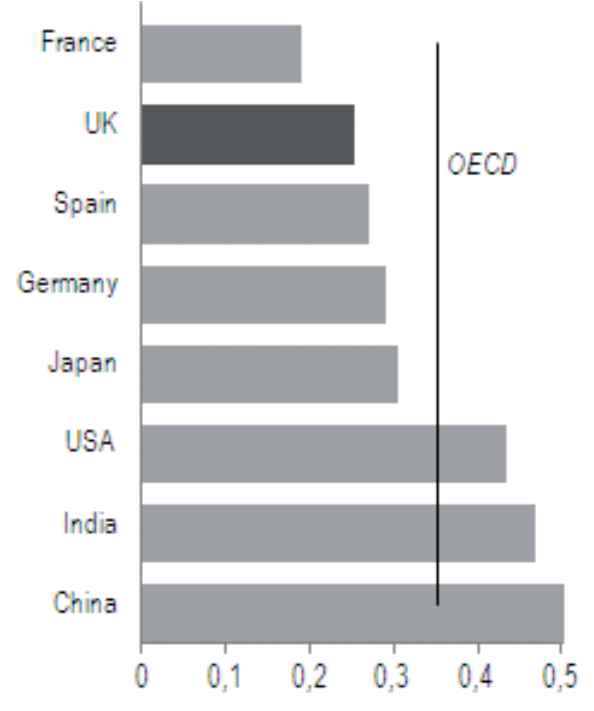

Climate policies. The UK has implemented ambitious climate policies, with the introduction of the Climate Change Levy and the launch of a domestic Emission Trading Scheme (ETS) ahead of the EU ETS. CO2 emissions intensity is already quite low compared to other key economies. The UK's Kyoto commitments under the EU's burdensharing agreement to cut emissions by $12.5 \%$ by $2008-2012$ has already been largely achieved, primarily due to structural change in the energy sector driven by the removal of subsidies to coal and the shift to natural gas. Further progress has been made with the recent plans by various departments on how to meet the 34\% cut in GHG emissions on 1990 levels by 2020 and an $80 \%$ cut by 2050 under carbon budgets.

$\mathrm{CO}_{2}$ Emissions intensities per unit of GDP (2007)

Source: OECD Environmental Data Compendium; IEA.

Green tax reform. At present, the Climate Change Levy $(\mathrm{CCL})$ includes rate reductions for energy-intensive



Revenues from environmentally related taxes

Source: OECD/EEA database on instruments for environmental policy industries, its tax rates do not reflect carbon contents (e.g. rate for coal is much lower than for cleaner natural gas) and households are excluded. Recent analyses show that a moderate energy tax like the CCL is more effective in promoting energy efficiency and fostering innovation than a quantity target negotiated with industry. Contrary to competitiveness concerns, the CCL was shown to have no discernable effect on output and employment. Currently all household energy use has a reduced VAT rate of $5 \%$ instead of the standard rate of $17.5 \%$. This rate reduction represents foregone tax revenues equivalent to $0.25 \%$ of GDP. "Fuel poverty" is better addressed with targeted support to low-income households rather than across-the-board tax reductions for all. 
Green investment. Public investment is still relatively low compared with other OECD countries and is set to fall sharply after 2010 as part of current plans to consolidate public finances. The June 2010 UK budget proposal envisions needs for GBP 200 billion of investment to 2020 in low-carbon energy. This will require reform of the energy market and measures to attract additional private investment in green infrastructure and technologies. Following the financial crisis, the UK could increase public investments in infrastructure that would facilitate private investment in new green technologies and industries.

\section{Recommendations}

Continued efforts are needed to encourage private investment in low-carbon sectors to spur green industries and jobs. This includes recent policies such as the introduction of differentiated support for varying renewable technologies, the Infrastructure Planning Commission's streamlined application process for green infrastructure projects and the proposal for a national Green Investment Bank.

The Climate Change Levy should be turned into a full-fledged carbon tax, with rates reflecting the carbon content of different fuels and phasing out rate reductions for energy-intensive industries. Key air emissions such as nitrogen oxides from industry could potentially be taxed as in Sweden, Denmark and Norway. In agriculture, a tax or a trading system on the nitrogen content of fertilizers (key water pollutants) could be considered as in Denmark. In transport, a broad-based road-pricing system could be introduced, in combination with a reduction in current motor fuel taxes. The rates ought to vary according to where and when the driving takes place, and according to the emission characteristics of the vehicles. These are win-win measures that help to green the economy while raising additional fiscal revenues.

Policy coherence for green growth calls for better coordination of domestic climate actions with the EU Emission Trading System to avoid duplicative policies, which can be costly to industry without achieving additional environmental gains. Firms should not be taxed for energy use already covered by the ETS, and electricity use should not be subject to a carbon tax as electricity generation is covered by the ETS. In the same vein, the efficiency of subsidies to reduce fossil fuel-based electricity usage should be considered, as there are already caps on emissions from the energy sector.

More measures to promote climate adaptation by private actors are needed. Climate change adaptation plans were released for every UK government department, outlining how they intend to cope with climate change impacts. The UK has coherent domestic policies on adaptation, with the Climate Impacts Programme, and more recently the Adapting to Climate Change Programme. While these public sector initiatives are commendable, more could be done to incentivise adaptation actions by private actors. Better costing of adaptation activities and developing methodologies to quantify the benefits of adaptation are areas where the UK is well placed to be a world leader.

\section{Key OECD Recommendations:}

- Further enhance integration of environmental concerns into national and sectoral policies in order to move towards green growth.

- Increase green public infrastructure investment to offset sharp fall after 2010.

- Institutionalise incentives to encourage private sector investment in green technology.

- Turn the CCL into a full-fledged carbon-tax, abolish the reduced VAT rate for domestic energy use and reassess the economic and environmental efficiency of other green taxes.

- Advance the use of economic and policy instruments to incentivise climate adaptation actions by private actors. 


\section{Education}

In recent years the United Kingdom made significant investments in the education system, raising upper secondary completion and bringing greater numbers of people to higher education than ever before. Individuals in the labour market and the economy and society more broadly reaped significant returns from these efforts. Nevertheless, due mainly to implementation difficulties, achievements so far have been mixed and significant further improvements in efficiency are required. The high proportion of pupils leaving school without upper secondary qualification is a major policy concern.

\section{Policy challenges}

Improving value for money and tackling under achievement. PISA scores show that student performance and school standards in the UK vary considerably and that the success of pupils remains tied to social background. Furthermore, even though spending per pupil in the early 2000s increased by 50 per cent, performance has remained virtually unchanged around the OECD average for pupils towards the end of compulsory schooling in key disciplines (mathematics, reading and science). Other OECD countries, Finland, Canada and Australia, for example, outperform the United Kingdom both in terms of quality and equity, although they spend less per student. Such high performing systems are often characterised by a climate of high performance expectations and the readiness to go the extra mile. They have pursued a shift in public and governmental concern away from the mere control over the resources and content of education towards a focus on outcomes, devolving responsibility to the frontline, encouraging responsiveness to local needs, and strengthening intelligent accountability. And they have embraced diversity of students by shifting from prescribed forms of teaching and curriculum towards an approach predicated on enabling every student to reach their potential, with a combination of curriculum entitlement and choice that delivers breadth of study and personal relevance.



Perhaps the most significant challenge for the UK is the high proportion of pupils leaving school without upper secondary qualifications, which translates into large earnings and employment penalties. Here the UK has slipped from rank 14 to rank 23 among the 31 OECD countries over past decades, not because the problem has worsened in the UK, but because many other countries have tackled it more successfully. Roughly one quarter of 15-19 year olds are not in education, which compares with an OECD average of $16 \%$.

Percentage of 15-19 year olds not in education (2007)

Source: OECD Education at a Glance 


\section{Recommendations}

Primary and secondary school reform. More progress would need to be achieved to meet the goal of universal quality services for all young children. Moreover, the United Kingdom needs to ensure that services for young children reach out to, and are used by, the most vulnerable families so that all children have the best possible start in life.

In order to raise value for money in schools, the UK could undertake an in-depth review to assess how the resources that are devoted to education can be used most effectively. This would require an analysis of the mix of factors that drive unit costs - student instruction time, teacher salaries, average class sizes and teacher's teaching time. Careful comparison with successful policy mixes in other countries could be a useful starting point. Finally, preventing drop-outs from secondary education may require more efforts to increase the quality of vocational education and training provisions, with priority given to a system of vocational education that enhances employer engagement with the institutions. The OECD supports the proposals from the UK Commission for Employment and Skills (UKCES), which include an emphasis on continued development of the apprenticeship system.

Higher education finance. Although the share of private contributions to funding higher education is one of the highest in Europe, there is scope for improving the balance of cost sharing between students and government further. This should be done by looking at different options capable of ensuring that fair access - including to the most sought-after institutions - is achieved. Other countries have for instance consolidated their universal student support system with an income-contingent loan system complemented with a scheme of means-tested grants to assist those students who would otherwise be prevented from attending university.

\section{Key OECD Recommendations}

- Simplify and stabilise the system of vocational education and training to enhance employer engagement with institutions and provide attractive and effective alternative pathways for students to remain in education.

- Ensure that the goal of universal quality services for all young children is achieved. In doing so, ensure that services for young children reach out to, and are used by, the most vulnerable families. Improve value for money in school education through establishing the most effective mix of the factors that drive unit costs - student instruction time, teacher salaries, average class sizes and teacher's teaching time.

- In further considering the balance of cost sharing between students and government in higher education, the charging of tuition fees should not be seen as a substitute for public funding but as an additional source of income for the sector. Greater variation in the fees charged for different programmes should not be ruled out. Fair access to higher education can be achieved through an effective balance of incomecontingent loans and means tested grants. 


\section{Employment}

The global economic crisis has hit the UK economy and its labour market hard. The UK unemployment rate rose by 2.7 percentage points since December 2007 to reach $7.9 \%$ in March 2010. This being said, the increase in unemployment has been relatively modest compared with other countries where the banking and housing sectors suffered strong reversals, in particular, Spain, Ireland and the United States. As elsewhere in the OECD, youth have been particularly affected. In 2009, employment fell by $8 \%$ for the 15-24 year olds compared with a drop of less than 1\% for workers aged 25 and over. Vulnerable groups, such as low skilled, immigrants and ethnic minorities, are also bearing the brunt of rising unemployment.

\section{Labour market outcomes of the UK during the current downturn}



ppc: percentage-point change.

Source: OECD Main Economic indicators Database and OECD calculations based on the European Union Labour Force Survey (EULFS) for the European countries, and from national sources for the employment by workforce groups.

\section{What are the issues?}

The UK labour market is characterised by relatively light employment regulations, combined with an effective activation strategy and, by OECD standards, a strong make-work-pay policy. All of these factors have contributed to a relatively low structural unemployment rate. This notwithstanding, there are a number of underlying structural problems in the UK labour market that have been heightened during the crisis, especially with respect to some workforce groups, notably unskilled youth and people with disabilities. In addition, the effectiveness of re-employment services offered by the UK public employment service (Jobcentre Plus) could be affected by staffing levels, which have not kept pace with the growth in the number of job-seekers during the recession.

Disadvantaged youth. Even before the recession, low-skilled 16 to 24 year olds in the UK performed slightly below the OECD average, and far below their high-skilled counterparts. The ratio of low-skilled to highskilled youth unemployment rates stood at almost five to one, the second highest in the OECD. Moreover, 14\% of 15-24 year olds were neither in employment, nor in education or training (NEET), against $11 \%$ on average in the OECD area. The NEET youth population has increased significantly during the crisis and many of those in this group are at high risk of poor labour market outcomes and social exclusion.

Disability benefits. At the onset of the job crisis, $7 \%$ of the working-age population were receiving disability benefits, 1.5 percentage points higher than the OECD average, and 3.5 percentage points higher than that observed in 1990. Past experience shows that entitlements do not shrink when the economy moves from a period of recession to recovery. However, over recent years, eligibility criteria to disability benefits have been tightened, the activation stance of system has been reinforced, and new measures recently announced by the Government take a step further in this direction.

Re-employment assistance to job-seekers. The introduction of the Flexible New Deal (FND) in October 2009 made significant changes to the activation strategy in force in the UK. In particular, the FND puts a greater focus on screening skills at an early stage of the unemployment spell, and transfers the responsibility for 
reintegrating the long-term unemployed onto private contractors. Evidence from Australia-as well as from the Employment Zones in the UK - has shown that the introduction of contestability and privatisation of placement services can increase the effectiveness of employment services. This notwithstanding, staffing levels at the UK public employment service (Jobcentre Plus) have not kept pace with growing demand during the recession. While the number of job-seekers registered with the PES increased by more than $75 \%$ between 2007 and 2009, PES staff increased by less than $5 \%$ over the same period.

The new Budget encompasses a number of measures that should help improve the matching process between job seekers to job vacancies which are to be welcomed. Reforms to the benefit system will make employment more attractive for those workers with low earnings potential. At the same time, the cut in employer contributions at the bottom end of the wage ladder should enhance employment opportunities for this workforce group.

\section{Recommendations}

Disadvantaged youth. Existing schemes to help unemployed youth get better skills and more effective jobsearch support rightly emphasise apprenticeship contracts that allow low-skilled youth to acquire both work experience and more skills. However, there is scope for better targeting apprenticeship places to jobless candidates: employers tend to offer places to youth already working for them. Furthermore, there is scope for achieving further increases in completion rates. For the most disadvantaged youth, more comprehensive and individualised programmes should be implemented.

Disability benefits. Further efforts should be made to promote the work-focus approach for people with remaining work capacity. While claimants are mandated to attend six monthly work-focussed interviews, also the outcomes of these activation assessments should become compulsory. Earlier intervention during the sick leave is also necessary to help workers with health problems to remain in employment and to avoid that sickness leaves be used as a route towards disability benefits.

Re-employment assistance to job-seeker. While the large fiscal deficit makes it essential to focus on costeffective programmes and target the most disadvantaged groups, labour market policies should remain adequately funded so as to avoid a large increase in long-term unemployment. Moreover, for the current reform of re-employment assistance to long-term job seekers to be successful, the contracts with private providers need to be designed very carefully to reward good outcomes and the individual performances of private providers must be accurately evaluated and rewarded.

\section{Key OECD Recommendations}

- Ensure adequate staffing of Public Employment Services to maintain the effectiveness of re-employment services provided to short-term job-seekers.

- Improve the apprenticeship system by using better selection, higher-quality off-the-job training and mentoring and supervision to get more young people successfully through apprenticeship schemes. Provide subsidies to promote apprenticeship for youth lacking skills and laid-off apprentices to help them to get a qualification.

- Strengthen reintegration supports for the most disadvantaged youth. Envisage a residential programme with a strong focus on remedial education, work experience and adult mentoring to provide intensive support for the hardest-to-place youth.

- Accelerate the early identification of health problems among the workforce. Medical control of a worker's health status should come earlier and be more frequent. The work capability assessment of workers on long sickness leaves should come before exhaustion of sick pay to minimize the risk that workers unable to return to their job are automatically transferred to a disability benefit.

- Underpin the conditionality approach in work integration programmes for people with disability. Strengthen participation requirements beyond the current mandatory interviews. For instance, make actions identified during these interviews increasingly compulsory and consider introducing similar requirements for as many current disability benefit recipients as possible. 


\section{Equity}

The gap between the rich and poor is greater in the UK than in three-quarters of OECD countries. Income poverty remains relatively widespread, especially among working-age people and children, despite improvements during the early 2000s. More than five million people in the United Kingdom suffer from multiple disadvantages beyond income, such as poor health, no qualifications or unemployment.

What are the issues and main policy challenges?

\section{Trends in income inequality, 1970 to 2008}

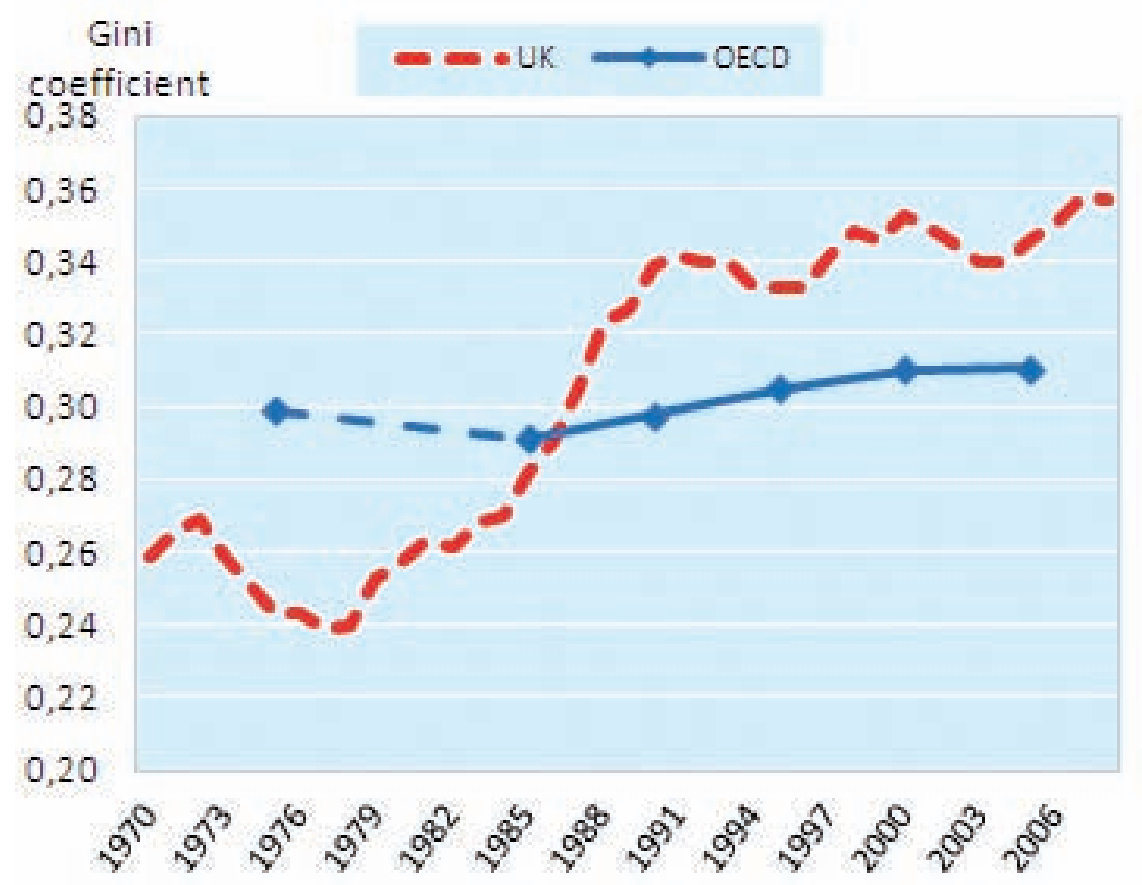

Source: IFS (2010), OECD (2008), Growing Unequal?, Atkinson, Piketty and Saez (2009). Gini coefficient refers to disposable income before housing costs. They range from 0 to 1 and indicate the degree of concentration of incomes.

Income inequality. Income inequality increased considerably more than in any other OECD country since the mid-1970s. This largely reflects the unequal distribution of earnings: the wage gap between the top and bottom 10 per cent of earners has widened by 20 per cent since 1985 . Incomes at the top of the distribution have increased much more rapidly than those of the population as a whole. A number of policies implemented by the previous government, such as the minimum wage and tax credits, stemmed further increases in income inequality but did not reverse the trend.

Poverty. Poverty rates for people of working age in the United Kingdom fell in the ten years to 2005, while other OECD countries experienced a slight increase. Nevertheless, nearly $14 \%$ of under 18 -year olds in the United Kingdom are income-poor, above the EU average of $12 \%$. Among the population as a whole, $12 \%$ live in income poverty in the United Kingdom compared with an average of $10 \%$ in the EU. In the United Kingdom, under-employment in addition to unemployment is an important driver of poverty.

Social and income mobility. OECD experience suggests that countries with a relatively low degree of income inequality typically have a higher level of earnings mobility between generations. The evidence for the UK is particularly disappointing: the unequal distribution of incomes is associated to comparatively low earnings mobility. Thus clearly income poverty is a persistent phenomenon which can last for generations of families and their children. 


\section{Income inequality and intergenerational earnings mobility}

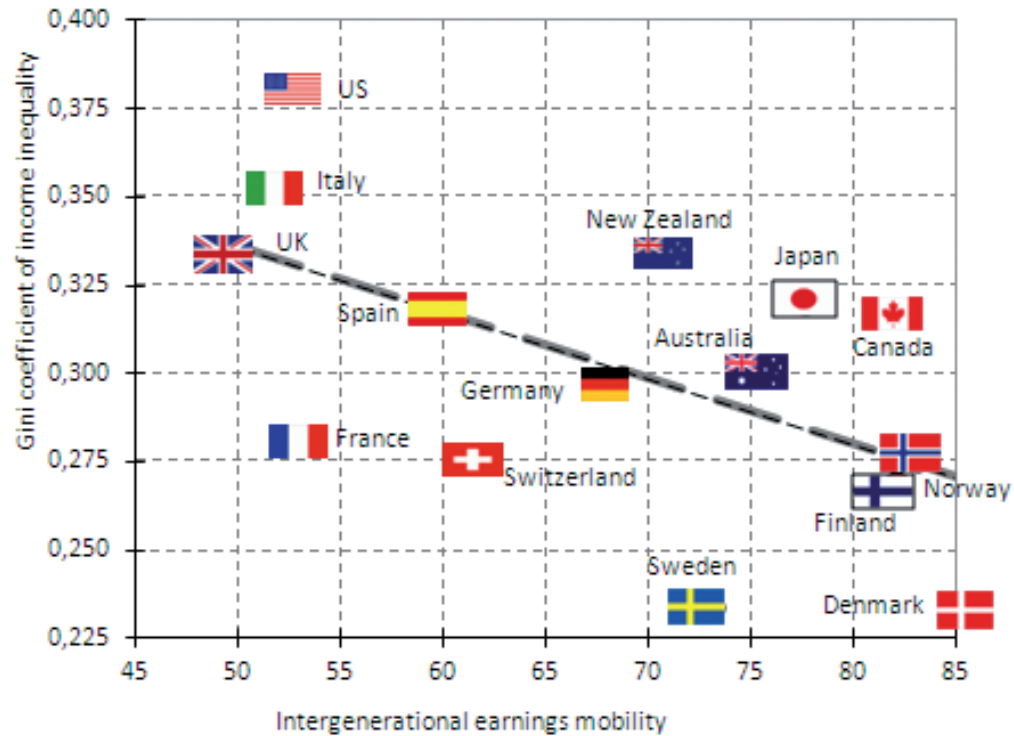

Source: OECD 2008, Growing Unequal? and d'Addio (2010).

\section{Policy recommendations}

Work is undoubtedly the main route out of poverty. Thus any policy initiative to reduce poverty has to include a strong focus on making work pay. Measures need to be taken to substantially reduce actual disincentives to work. One specific problem is in the current system of tax credits, which still implies high marginal effective rates of taxation for the most vulnerable. For example, lone parents returning to a formerly held low-wage job lose two pounds out of every three earned through taxation or foregone benefits. Furthermore, the marginal effective reduction in income is $40 \%$ for a second earner in a couple, whilst below the average for OECD countries.

Increasing intergenerational mobility of earnings in the $\mathrm{UK}$ also requires better educational attainments - one's own but also parental educational achievement. The experience of the OECD countries clearly shows that education can go a long way in shaping the life chances and working opportunities of children, ultimately supporting labour utilisation and long-term growth.

Complementary measures are to be found in the policies to help the reconciliation between work and family time. OECD evidence suggests that carefully designed employment-conditional benefits and tax credits may prove a powerful tool to improve work incentives, especially among low-wage workers. Such tax credits need to be well co-ordinated with the entire benefit system, in order to increase take-up and avoid inactivity and low-wage traps.

\section{Key OECD Recommendations}

- Increase efforts to make work pay and to help workers find and retain work.

- Ensuring access to good-quality early childhood education and care to offer protection against the lack of resources in the parental nest and help combat social and residential segregation.

- Enabling parents to invest (time or money) in children is essential; hence, the need for more familyfriendly policies.

- Reducing child poverty by focusing on large families and under-employed households. 


\section{Health}

Many efforts have been made to improve the UK health care system since the early 2000s. Historically low spending was increased, as a percentage of GDP, reducing the spending gap with continental Europe. Yet, performance indicators suggest that inputs rose faster than outputs, implying a fall in productivity. Population health still lags behind the best OECD performers in some key areas. Notably, amenable-to-interventionsmortality remains higher than for the best OECD performers, albeit it has been decreasing. Problems with lifestyles, particularly obesity and binge-drinking, are more serious than elsewhere. To meet diminished funding growth, following fiscal consolidation, the NHS chief executive must be successful in achieving planned $£ 15-20$ bn of efficiency savings if new demand pressures are to be met without deficits emerging.

Total expenditure on health

(as a percentage of GDP)

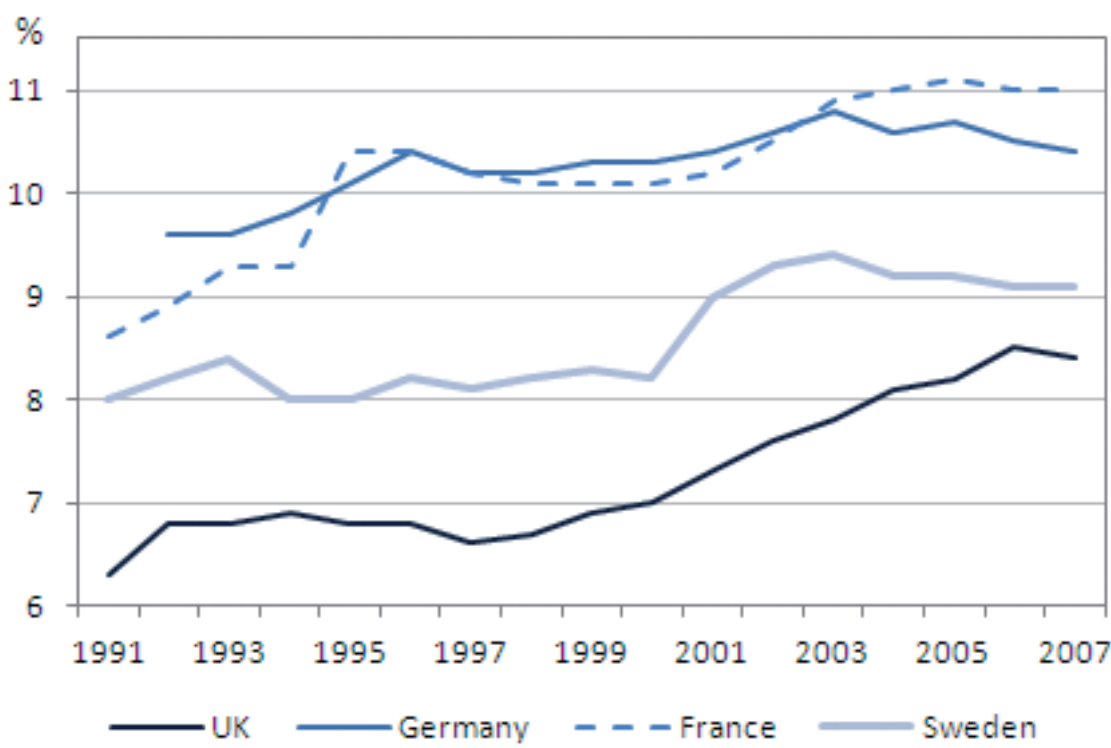

\section{Key issues and major challenges}

The need to improve purchaser-provider mechanisms. During the past decade, purchasing responsibilities over health services were moved to the newly created system of Primary Care Trusts (PCTs). Under the reforms that are currently being envisaged, however, this crucial function may be reallocated to the general practitioners - themselves organized in consortia. There are two problems with the UK health system that such a reform might address. One is the failure to make much progress in tackling lifestyles that lead to poor health - particularly obesity and drinking. These contribute to poor health outcomes, particularly in lower socioeconomic groups and in poor areas of the country. If the new reforms were to give GPs powers to commission public health services such as anti-obesity campaigns and counseling services for smokers, they may be able to come up with innovative and effective ways of reaching people. The second is that the NHS has become increasingly bureaucractic. By placing responsibility more clearly with GPs, it may be possible to reduce the targets and administration which cause the health workforce so much dismay. However, the experience of the PCTs shows that commissioning services is a technically demanding task, and a great deal of capacity development may be necessary before GP consortia operate effectively. Furthermore, the timing of such a reform may not be propitious, given the state of public finances, as nearly all successful health reforms require increased funding initially, even if eventually they increase efficiency. 
Reducing bureaucracy in the National Health Service (NHS). The new government considers that excessive bureaucracy and waste in the NHS act as key drivers to rising costs. Evidence suggests that the UK health system spends less on administrative costs than many other health systems, but it is indeed true that the number of managers, accountants and other administrative workers has for many years been expanding more rapidly than the numbers of front-line staff - doctors and nurses - thus partly offsetting the typical cost advantages of having a single funder system. Furthermore there is evidence that some providers end up being more concerned with meeting targets than delivering appropriate care.

These shortcomings can be traced back to reforms of the past twenty years. These aimed to change the NHS - historically heavily centralised - to a more devolved, market-oriented system. However, the need to reduce waiting times and improve quality meant that the authorities were unwilling to let providers 'get on with it', and instead imposed many targets and demands. The result has been impressive in some respects - quality has gone up more rapidly than in other countries (see charts below) though much still remains to be done, and waiting times have fallen. The new government wants to free providers from targets and bureaucracy to improve efficiency, but needs to find the magic balance between laissez-faire and control that eluded its predecessor.

Age-standardized death rates from amenable causes among males, age 0-74

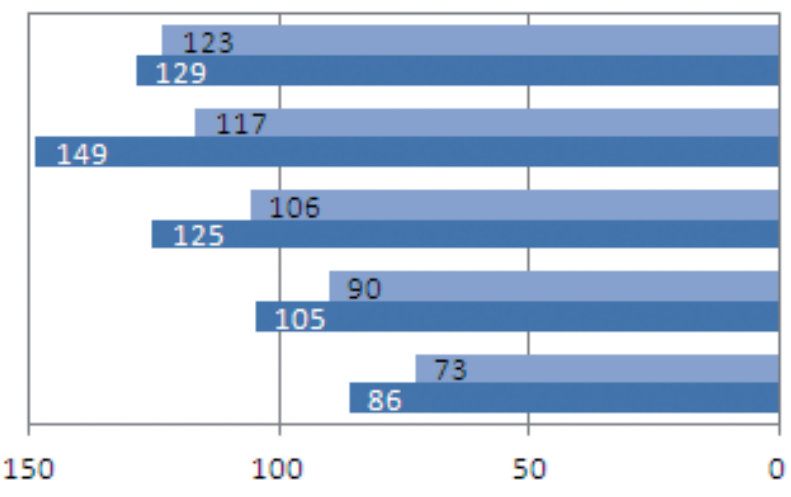

2002-03 $\quad 1997-98$
Age-standardized death rates from amenable causes among females, age 0-74

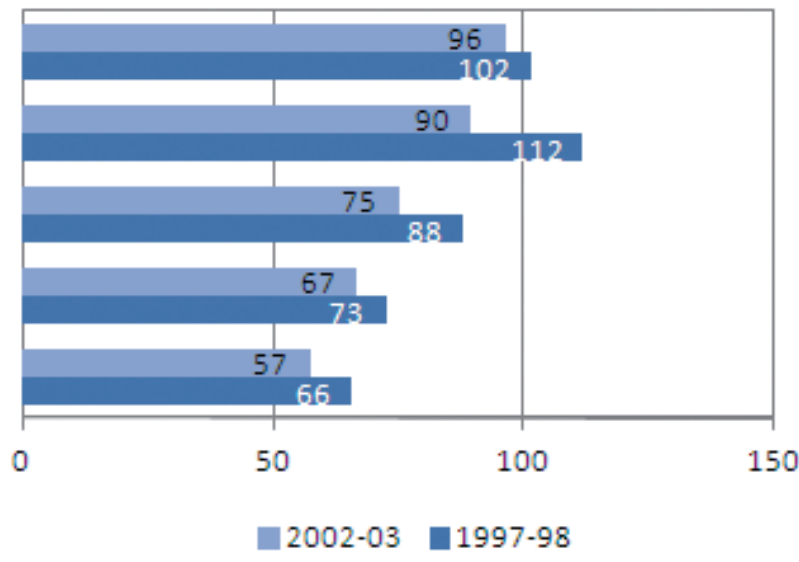

Source: Nolte E. and McKee C.M. (2008) “Measuring the Health of Nations: Updating an Earlier Analysis”, Health Affairs 27, 1(2008): 58-71

\section{Policy recommendations}

The central objective of policy needs to be the repositioning of GPs to play a central role in the health system: not simply delivering individual treatments, but caring for the health of the population more generally. This requires an upgrade of the purchaser/provider split, encouraging general practitioners (collectively) to design health services to take into account local conditions. Examples from Sweden, and the Local Health Integrated Networks in Ontario, Canada, are far from perfect but are useful models to learn from. After two decades of targets and tight controls, it is reasonable to move towards more self-management by health providers. This will reduce bureaucracy. However, providers need to be confronted with their performance, relative to others. The UK has invested heavily in the health information infrastructure; it is now time to learn from Denmark and the Netherlands as to how to use the data to ensure that quality improvements continue, even when targets are dropped or relaxed. Placing GPs at the heart of the system can also permit better co-ordination of care. Examples from the United States such as Medical Homes, Kaiser and the Veteran's Administration show that integrated care can deliver better and cheaper care. This would also permit a reevaluation of roles of the health workforce, to see a broadening of non-physician inputs through broadening nursing and pharmacist roles and making more and better use of physician assistants. 


\section{Key OECD Recommendations:}

- General practitioners need to be placed at the centre of the health system, responsible for commissioning population health services, not just treating individual patients.

- Greater self-management by health professionals can reduce bureaucracy, but if rapid improvements in quality of care are to be continued, information on the quality of health providers needs to be made widely available.

- Tackling health inequalities needs to be a priority for GPs, hospitals, other health care providers, and the UK government should reward health providers who are particularly successful.

- Co-ordinated care should be encouraged by promoting integrated care models.

- Further reallocation of tasks from physicians to other health professionals can lead to higher quality, more efficient care. 


\section{Tax Policies}

The overall tax burden in the UK is broadly in line with the average for OECD countries - see table 1 below. By international standards the UK is not 'under-taxed', but (as in many OECD countries) this ratio looks likely to rise. The key focus of tax policy reforms is to be growth-friendly, while addressing not only shortterm but also longer-term challenges (such as population ageing) to sustainable public finances. The key to a durable recovery will be achieving sustainable, private-sector led growth. This points to reducing the extent to which tax distorts business and household decisions, particularly incentives for work, saving, investment and entrepreneurship; and to raising additional taxation through reforms that broaden the tax base, while reducing (top) marginal rates.

\section{Tax Burdens and Tax Rates}

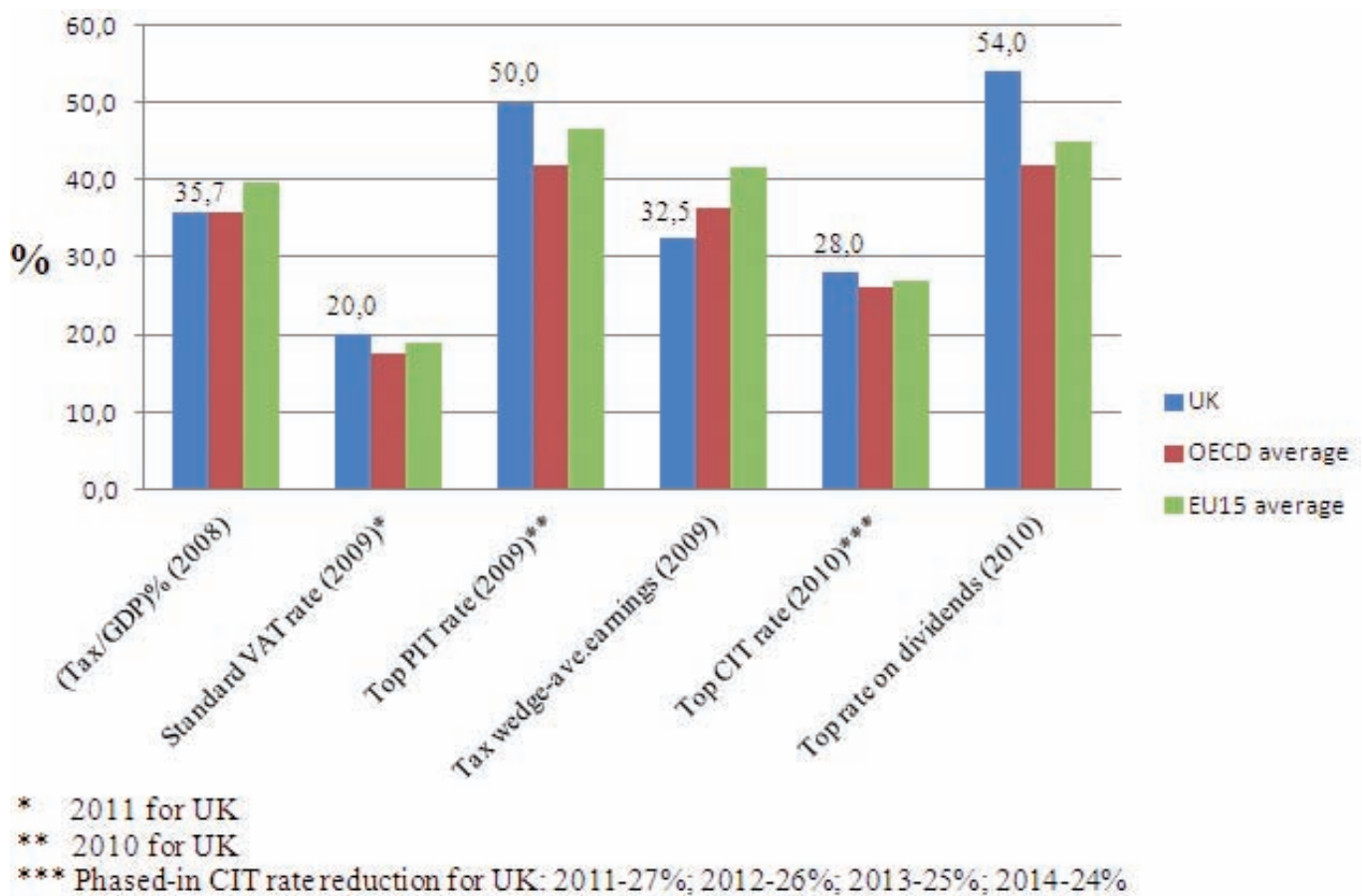

\section{Main policy challenges}

VAT. The reduced rate of VAT for domestic consumption of fuel and power looks particularly anomalous, given the UK's commitments to reduce emissions of greenhouse gases (GHG). Achieving these targets will inevitably involve making it more expensive to emit GHG through taxes and tradable permit regimes. Such measures will feed through into consumer prices to some degree. There is thus a risk that the UK would end up with a more complex (and distortive) tax regime that does not even achieve its putative distributional objectives, if it continues to apply only the reduced VAT rate to domestic fuel and power. Moreover, the June Budget does not address the issue of broadening the VAT base, which is relatively narrow, with reduced rates that are comparatively low. The current system tends to distort consumption, while also increasing complexity and thus imposing significant tax administration and compliance costs.

Personal income tax (PIT) and social security contributions (SSC). The UK's overall PIT and SSC regime is relatively 'employment-friendly' (to judge by the tax wedge on average earnings - see table). On the other hand the combined effect of PIT and SSCs with the withdrawal of tax credits (and Income-Related Benefits), 
leaves almost 2 million working heads of households facing marginal combined deduction rates of over $60 \%$. Simplifying the tax-benefit regime and improving work incentives would be a highly desirable medium-term objective.

Corporate Income Tax. The Government's plan for a phased reduction in the main CIT rate (to maintain its international competitiveness) and to maintain a $20 \%$ small profits rate will widen the gap between CIT and PIT rates. Low CIT rates can encourage firms to cut their tax bills by changing business form and recharacterising income, without any beneficial effects on investment or enterprise.

Property taxation. The Budget makes no substantial changes to stamp duties on property transactions, which tend to reduce the liquidity of the property market and discourage households from moving house when the place of employment or family circumstances change - tending to reduce labour mobility, increase travel to work (and congestion) and reduce household economic well-being. While the UK raises significant revenues from recurrent taxes on property (Council Tax), this tax could potentially be made fairer and less distortive.

\section{Policy recommendations}

Consider a gradual alignment of VAT rates in a medium-term strategy. Particularly, the effectiveness of the current zero and reduced VAT rates in achieving distributional objectives needs to be carefully assessed. There may be other means to meet the same objectives without distorting consumption (e.g. an increase in the basic personal income tax allowance, as in the current Budget which increased this allowance by $£ 1000$ ). Furthermore, VAT rates for domestic fuel and power should be increased.

Consider reducing the top rate of PIT, which is substantially above the OECD average and likely to adversely affect work incentives and entrepreneurship, particularly of high skilled workers. Consideration should be given to reducing the top PIT rate to close to 40 per cent.

Reform to the way the corporate and personal tax regimes fit together could also help coherence. It would involve greater taxation at the individual level through higher tax rates on dividends and capital gains (i.e. when profits are taken out of a company or shares in it are sold).

Establish a more coherent tax regime for savings. The review of pension tax relief should be extended to focus on the overall tax treatment of savings in different investments. Similarly the review of small business tax should look at the effects of the growing disparity between personal and corporate tax rates.

The taxation of residential property could be made fairer and less distortive by shifting the balance away from the current system of stamp duties on property transactions, towards recurrent (e.g. annual) taxes levied on property values aligned closely with current market values.

Key OECD Recommendations
- The UK is encouraged to evaluate the effectiveness of its current zero and reduced VAT rates in achieving
distributional objectives.
- In the context of policies to reduce greenhouse gas emissions, the reduced VAT rates for domestic fuel
and power, for instance, look hard to justify
- The UK's top rate of personal income tax is substantially above the OECD average and likely to adversely
affect work incentives and entrepreneurship.
- The reviews of pension tax relief should be extended to produce a more coherent overall tax regime
for saving. Similarly the review small business tax should look at the effects of the growing disparity
between personal and corporate tax rates.
The taxation of residential property could be made fairer and less distortive by shifting the balance from
stamp duties toward recurrent taxation and by aligning the tax base more closely with market property
values. The valuation of land and building could be outsourced.




\section{Public Governance}

The cost of producing public services in the UK is well above the OECD average and has risen significantly over the past decade. This reflects in particular higher costs of inputs purchased by government rather than an excessive wage structure. A significant proportion of deficit reduction is expected to come from cuts in the public sector spending and efficiency gains. In addition, the government has announced plans to create a larger space for local service delivery, emphasising "co-design" and "co-delivery" approaches.

Production costs: Costs of government-produced and government-funded goods and services, 1995 and 2007

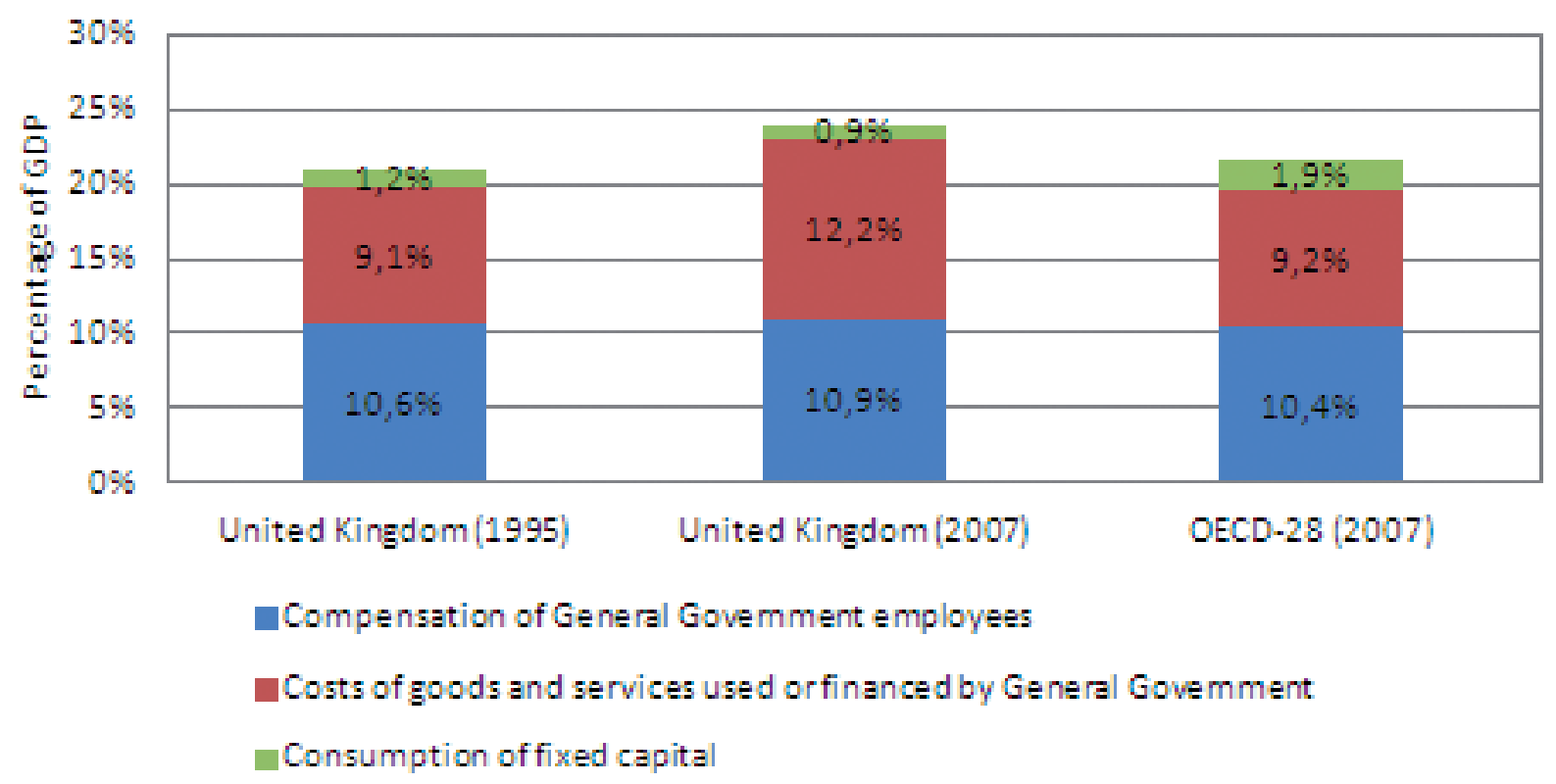

\section{Policy Challenges}

Reforming the public sector and getting to grips with public spending are the key challenges. Reform of the way government operates, how it manages its finances and its interactions with business and citizens are key priorities of the new government. The administration has indicated that it wants to move from a centralised, bureaucratic system to more decentralised governance arrangements with greater powers devolved to local authorities and, in some cases, to citizens themselves. This is a fundamental review of public governance and needs to be pursued in a "whole of government" manner, co-ordinated from the centre in a way that ensures collective commitment across the entire public administration.

\section{Recommendations}

Fiscal consolidation through sound budget management. Reducing the deficit stands out as the main challenge that the new government has set for itself. OECD shares the UK government's position that fiscal consolidation is a policy for growth and is currently defining a set of agreed principles for sound budgeting. These principles could serve as a useful base for monitoring progress. One of the key measures announced by the new government is the creation of the Office for Budget Responsibility (OBR). This is clearly an important initiative in terms of strengthening government management of public spending and improving public confidence in the government's fiscal policy. The experience of OECD with establishing similar bodies in Canada, Korea, Austria, Hungary, and Sweden suggests that in such bodies clear signals of impartiality are important. At present, the interim UK body is housed inside the Treasury, its Director appointed by the 
Chancellor, and its staff seconded from the Treasury. A more permanent set up at arm's length from the Treasury could be considered in order to fully benefit from the new body as our cross-country-experience has shown.

Making government more open and transparent. The new government has expressed a commendable commitment to openness and transparency. The reform programme emphasises both disclosure (putting public databases on-line with public access) and accountability (measures to enable citizens to hold politicians responsible for their actions). The commitment of the UK government to open up government procurement (e.g. publish all new central government tender documents for contracts over $£ 10,000$ on a single website) is an important step. The government's decision to regulate lobbying by introducing a statutory register of lobbyists is another good move. Canada and, more recently, Australia, provide good examples against which the UK could benchmark progress with its lobbyist register. The UK has a complex institutional environment and the rationalisation proposed by the new government is much needed. To ensure that the regulatory framework reflects this open government approach, there is a need to step up quality control of ex-ante impact assessment of new regulations, at both central and local levels, to avoid unnecessary rule-making. As the UK follows the EU trend of more streamlined contact between citizens and the administration, the regulatory framework, which is currently very business-focused, will have to adapt. A similar process of reducing the administrative burden of citizens in their daily lives has been established quite successfully in the Netherlands. Finally, much of this open government approach depends on e-government. Several big ticket e-government ICT-led projects are now being reconsidered, with the likelihood being that smaller scale projects will be preferred. A review of the government's e-government strategy might now be required in order to take account of this new orientation and the implications of spending cuts.

\section{Key OECD Recommendations}

- Assess the relevance of OECD's principles for sound budgeting to help ensure that the government's fiscal strategy is consistent and credible. The OBR is an important step in the right direction. Other principles for sound budgeting should also be taken into account.

- Review the e-government strategy in light of spending cuts affecting headline e-government initiatives and the emphasis on new governance arrangements.

- Take the openness agenda forward in two key areas - procurement and lobbying. The OECD's Principles for Integrity in Public Procurement and Principles for Transparency and Integrity in Lobbying provide innovative instruments and examples of good practice that could help this process.

- Rationalisation of institutions, particularly quangos, is needed to simplify the regulatory framework.

- The UK has a strong business-oriented regulatory framework. Better regulation aimed at public sector workers and at citizens are important complements to business-oriented measures. 


\section{Regional Policy}

Inequalities have been increasing steadily over the past 25 years (see figure below) despite the commitment of previous governments to reducing the growth rate gap between the south east and the rest of the country. Strong growth in the south has led to out-migration from the north and captured large shares of private investment, with the north having persistently higher levels of unemployment and an increasing income gap. As such, the problem of inequalities has a strong spatial dimension. The regional policy debate in the UK has been re-launched by the new government, which has scrapped the network of regional development agencies (RDAs) and challenged local governments to take a more direct role in leading economic development. While the role of the RDAs in strategic investment planning has been controversial from the outset, it is clear that some form of regional policy is still warranted. In this changing framework the government could embark on a comprehensive review of regional policy with a view to clarify the government's objectives and the suitability of the instruments in place or planned.

Gini index of inequality in GDP per capita (TL2 regions)



Note; The Gini index is a commonly used measure of inequality, with 0 representing low inequalities and 1 representing high inequalities. Regions are at TL2 (NUTS2) level (UK administrative regions - North East, South East, etc.).

OECD (2010) Regions Matter, OECD Publishing, Paris

\section{Policy challenges}

If decentralisation tends to favour stronger local authorities, there is the risk that poorer areas will continue to fall behind, causing potentially costly drags on national economic performance and potentially exacerbating tensions generated by cuts in public services. As such, retaining some mechanism for implementing strategic investment in lagging regions is probably sensible. Despite the financial crisis, countries such as Canada have nonetheless recognized that supporting lagging regions remains a key national economic policy imperative, while others (France, Portugal) have adopted "asymmetric" decentralisation to permit region-specific institutional solutions. 


\section{Recommendations}

A clearer policy for rural areas is required. Rural areas pose a particular challenge, as was highlighted in a recent OECD review of rural policy in the UK. The report noted that "mainstreaming" -- the Government's approach to ensuring consistent delivery across all regions - has been an effective means to bridge the ruralurban divide in policy design. In lieu of specific rural policies, it has allowed the government to focus on developing policies in all ministries and agencies to deliver benefits to all citizens no matter the place. However, the more limited capacities and fiscal autonomy of local governments in rural regions, added to demographic specificities and rural issues such as land use, service delivery and affordable housing, suggest that a more clearly defined rural policy and governance framework will be needed once responsibilities are decentralised.

Coordinating across levels of government will be a key challenge. Decentralisation is a cornerstone of the new government's thinking on the reorganisation of government, with more responsibility to be given to local authorities. This will intensify the debate about the role and funding of local government. Concern about fiscal gaps and unfunded mandates have already been voiced by local councils.

Sub-national authorities are responsible for an average of 31\% of total government spending and $64 \%$ of public investment in the OECD (55\% in the UK). In the current context, most sub-national governments have to cope with a scissor effect of declining tax revenues and rising expenditures. UK local authority spending is strongly concentrated in education and social protection. The first domain is a key condition for building competitive advantage for the future while the second will be strongly demanded once unemployment grants (paid by the central government) reduce. Fiscal consolidation programmes thus need to be coordinated with sub national authorities if they are to achieve their goal of reducing spending without harming growth potential. A reconsideration of the current allocation of competences and public funding sources is suggested. The UK may want to explore the use of mechanisms that allow public policies and sub national institutions to be adapted to specific territorial opportunities and needs.

Another important issue is how to deliver policy to more functional areas once the network of Regional Development Agencies has been scrapped. The regional structures of the Regional Development Agencies were one means by which to deliver strategic investment to larger regions, another option is the "city-region" concept. It will be important to find ways to aggregate across administrative units to achieve an efficient scale for policy delivery. The previous government had introduced local area agreements, similar to the contrats d'agglomeration in France, and had proposed city-region structures for metropolitan areas. These will need to be further strengthened.

\section{Key OECD Recommendations}

- A comprehensive review of the objectives and instruments of regional policy is needed in order to learn from past experience and reform the policy in a constructive way.

- Governance reform should avoid creating tensions between leading and lagging regions. Institutional structures have to be adapted to territorial contexts. RDA-type structures still have a valuable role to play in lagging regions and rural areas. In metropolitan areas, "city-region" governance structures could define pro-competitiveness strategies across functional areas.

- Decentralisation raises issues of fiscal gap and makes close coordination a conditio sine qua non. Fiscal consolidation will put additional pressure on sub-national governments. As such, close co-ordination between the centre and local governments over spending cuts will be necessary to avoid adverse impacts on the quality of public services. The UK's well-developed evaluation mechanisms at all levels can help in prioritising public spending. 


\section{ORGANISATION FOR ECONOMIC CO-OPERATION AND DEVELOPMENT}

The OECD is a unique forum where governments work together to address the economic, social and environmental challenges of globalisation. The OECD is also at the forefront of efforts to understand and to help governments respond to new developments and concerns, such as corporate governance, the information economy and the challenges of an ageing population. The Organisation provides a setting where governments can compare policy experiences, seek answers to common problems, identify good practice and work to co-ordinate domestic and international policies.

The OECD member countries are: Australia, Austria, Belgium, Canada, Chile, the Czech Republic, Denmark, Estonia, Finland, France, Germany, Greece, Hungary, Iceland, Ireland, Israel, Italy, Japan, Korea, Luxembourg, Mexico, the Netherlands, New Zealand, Norway, Poland, Portugal, the Slovak Republic, Slovenia, Spain, Sweden, Switzerland, Turkey, the United Kingdom and the United States. The European Union takes part in the work of the OECD.

OECD Publishing disseminates widely the results of the Organisation's statistics gathering and research on economic, social and environmental issues, as well as the conventions, guidelines and standards agreed by its members.

\section{OECD “Better Policies” Series}

The Organisation for Economic Co-operation and Development (OECD) aims to promote better policies for better lives by providing a forum in which governments gather to share experiences and seek solutions to common problems. We work with our 34 members, key partners and over 100 countries to better understand what drives economic, social and environmental change in order to foster the well-being of people around the world. The OECD Better Policies Series provides an overview of the key challenges faced by individual countries and our main policy recommendations to address them. Drawing on the OECD's expertise in comparing country experiences and identifying best practices, the Better Policies Series tailor the OECD's policy advice to the specific and timely priorities of member and partner countries, focusing on how governments can make reform happen. 
